\title{
The Relationship between Jurisdiction and Attribution after Jaloud v. Netherlands
}

\author{
Jane M. Rooney ${ }^{1}$
}

Published online: 5 November 2015

(C) The Author(s) 2015. This article is published with open access at Springerlink.com

\begin{abstract}
This article argues that the European Court of Human Rights (ECtHR) in Jaloud $v$. Netherlands adopted an attribution test in order to establish jurisdiction under Article 1 of the European Convention on Human Rights. It argues that this would not be the first time that the ECtHR has adopted an attribution test in order to establish Article 1 jurisdiction. Furthermore, the article challenges the proposition that the ECtHR's adoption of an attribution test to establish jurisdiction is methodologically unsound and not in conformity with international law. It proposes moving beyond this debate and considering the real challenges that an attribution test of Article 1 jurisdiction poses for the future.
\end{abstract}

Keywords Jaloud v. Netherlands - Extraterritoriality - State responsibility · Fragmentation of international law $\cdot$ Military intervention

\section{Introduction}

The relationship between jurisdiction and attribution in the European Court of Human Rights' (ECtHR) approach to the extraterritorial application of the European Convention on Human Rights (ECHR) has been the subject of much speculation. ${ }^{1}$ Article 1 of the ECHR provides that a state must secure to everyone "within its jurisdiction' rights under the ECHR. The ECtHR has interpreted Article 1 as providing grounds for when a state's obligations under the ECHR extends outside of its territory. Al Skeini v. United Kingdom confirmed that a state will have

\footnotetext{
${ }^{1}$ Gondek (2009), pp. 162-168; Milanovic (2011), pp. 41-53; Lawson (2004), pp. 85-88.

Jane M. Rooney

jane.rooney@durham.ac.uk

1 Durham Law School, Palatine Centre, Stockton Road, Durham DH1 3LE, UK
} 
extraterritorial jurisdiction when a state exercises control over a territory ${ }^{2}$ or when a state exercises authority and control over an individual. ${ }^{3}$ However, there is much speculation as to whether an attribution test for establishing Article 1 jurisdiction also exists in the ECtHR's jurisprudence.

The decision of Jaloud $v$. Netherlands has recently provoked renewed interest in the question. ${ }^{4}$ Various interpretations of the ECtHR's approach in articulating the relationship between attribution and jurisdiction have been put forward. One interpretation is that the ECtHR has kept separate the question of jurisdiction from attribution: an attribution test precedes the jurisdiction question and another attribution test succeeds the jurisdiction question. ${ }^{5}$ Another interpretation of Jaloud v. Netherlands is that while the ECtHR has ensured that the jurisdiction test remains separate from a test of attribution, the preceding and succeeding attribution tests have been conflated. ${ }^{6}$ This article seeks to identify the approach the ECtHR took in Jaloud v. Netherlands. It also seeks to revisit and challenge some of the propositions made regarding the relationship between Article 1 jurisdiction and attribution. It proposes that the ECtHR conflated the concepts of jurisdiction and attribution in Jaloud v. Netherlands. Furthermore, it demonstrates that the ECtHR has adopted an attribution test to establish jurisdiction under Article 1 in previous decisions. Finally, it challenges the idea that the adoption of an attribution test as a test of jurisdiction by the ECtHR would be methodologically unsound and contrary to international law on state responsibility.

An 'attribution' test determines who should be held responsible for a rights violation rather than whether a state's obligations are engaged extraterritorially in the first place. An attribution test is normally applied when a variety of actors are involved in the relevant events and it is not obvious which actors in the context should be held responsible for a rights violation. In this context, an attribution test may be applied to the exclusion of the application of the two traditional jurisdiction tests confirmed in Al Skeini: control over an individual and control over a territory. Unlike the state agent authority and control test, an attribution test does not aim to establish whether the state agent exercised a particular kind of control over the individual such as "physical force" ${ }^{7}$ or "custody' 8 in order to trigger the application of the ECHR extraterritorially. Unlike the control over a territory test, an attribution test does not aim to establish whether there is sufficient military presence for a sufficient period of time to establish jurisdiction ${ }^{9}$ or whether a particular space, such as a prison or boat constitutes a 'territory' for the purposes of that test. ${ }^{10}$

\footnotetext{
${ }^{2}$ Al Skeini v. United Kingdom, app. no. 55721/07, (2011) 53 EHRR 18, para. 138.

3 Ibid., para. 138.

4 Jaloud v. Netherlands, app. no. 47708/08, 20 November 2014.

5 Milanovic (2014).

${ }^{6}$ Sari (2014), pp. 288, 289.

7 Öcalan v. Turkey, app. no. 46221/99, 12 May 2005, para. 93.

${ }^{8}$ Al Skeini, supra n. 2, para. 136.

9 Issa v. Turkey, app. no. 31821/96, 16 November 2004, para. 75.

10 See e.g. Medvedyev v. France, app. no. 3394/03, 29 March 2010, paras. 66-67; Al-Saadoon v. UK (dec.), app. no. 61498/08, 30 June 2009, para. 88.
} 
Distinguishing an attribution test from a jurisdiction test when interpreting the ECtHR's jurisprudence can be a matter of emphasis. The main difference in emphasis is that an attribution test is concerned with determining who should be held responsible rather than whether the ECHR is applicable abroad. In this way, an attribution test signals a lack of concern by the ECtHR that the actions took place abroad. The arbitrary delimitation on the extraterritorial application of the ECHR provided by the two jurisdiction tests confirmed in Al Skeini is no longer applicable. That territory does not constitute a barrier to accountability under the ECtHR in cases where an attribution test is applied instead of the traditional jurisdiction tests, may account for the lack of acknowledgment of conflation of attribution with jurisdiction by the ECtHR.

Firstly, this article will provide an analysis of the reasoning in Jaloud $v$. Netherlands. It attempts to de-mystify the ECtHR's judgment, putting forward an interpretation of the ECtHR's reasoning that provides that the ECtHR conflated the concepts of jurisdiction and attribution. Secondly, the article argues that Jaloud is not the first case in which the ECtHR has adopted an attribution test to establish jurisdiction under Article 1. It will be argued that an attribution test was used to determine whether a state had jurisdiction in relation to the 'effective control' test. It illustrates that there were two sub-tests of 'effective control' applied by the ECtHR: a 'control over the territory' test, and an 'attribution' test. This proposition is in contrast to the assertion that there was mere conceptual confusion between the two concepts in the ECtHR's case law. ${ }^{11}$ The 'control over the territory' sub-test provides that Article 1 jurisdiction will be established when a state exercises control over a territory, and the 'attribution' sub-test provides that it will be established when the state exercises a degree of control over entities carrying out the rightsviolation. The precise nature and standard of control in each instance will be explored in an analysis of the relevant cases. In its application of the 'attribution' sub-test the ECtHR failed to acknowledge that it conflated jurisdiction and attribution. However, this does not preclude the argument that the ECtHR does in fact apply an attribution test to establish jurisdiction in these circumstances: commentators openly acknowledge that the ECtHR's cognisance of its own practices in relation to its treatment of jurisdiction and attribution is not indicative of its actual approach. ${ }^{12}$

Thirdly, the article challenges the proposition that the ECtHR's adoption of an attribution test to establish Article 1 jurisdiction would be methodologically unsound and not in conformity with international law on state responsibility. It has been argued, firstly, that the conceptual framework of Article 2 of the International Law Commission's (ILC) Articles on State Responsibility (ASR) ${ }^{13}$ indicates that attribution and Article 1 jurisdiction are separate questions ${ }^{14}$; and secondly, in cases where the ECtHR purportedly adopts an attribution test to establish jurisdiction,

\footnotetext{
11 Milanovic (2011), p. 41.

12 Milanovic (2014); Sari (2014), p. 293.

13 ILC, 'Report of the International Law Commission on the Work of its 53rd Session', UN Doc. A/56/ 10, 12 December 2001.

14 Gondek (2009), pp. 165-168; Milanovic (2011), pp. 51-52.
} 
those attribution tests are not in conformity with the attribution test prescribed by the ASR and case law of the International Court of Justice (ICJ). ${ }^{15}$ It will be argued in response to the first proposition that the conceptual framework of the ASR appears to have nothing to say about the relationship between jurisdiction under international human rights treaties and attribution under the law of state responsibility, and therefore does not offer any methodological guidance on the relationship between the two concepts. In response to the second proposition it will be argued that the ECtHR, in conformity with international law, could justify a different attribution test to that stipulated by the ICJ and the ASR.

Jaloud $v$. Netherlands has provided a new opportunity to clarify the relationship between Article 1 jurisdiction and attribution in the ECtHR's extraterritoriality case law, and to revisit arguments for and against the availability of an attribution test to establish jurisdiction. This article seeks to illustrate that the ECtHR has in fact used an attribution test to establish jurisdiction in previous cases. It then seeks to evaluate whether this is desirable or not. It addresses and answers old challenges against an attribution test for establishing Article 1 jurisdiction, with the intention of allowing the real concerns relating to conflating attribution and jurisdiction to come to the fore.

\section{Jaloud v. Netherlands}

\subsection{The Facts and ECtHR's Assessment}

In Jaloud v. Netherlands, an unknown car approached a vehicle checkpoint in South Eastern Iraq. ${ }^{16}$ From inside the car shots were fired at the personnel guarding the checkpoint, all of them members of the Iraqi Civil Defence Corps (ICDC). The guards returned fire. No one was hit and the car drove off. ${ }^{17}$ The checkpoint commander called on a patrol of six Netherlands soldiers led by a Lieutenant. ${ }^{18}$ Another car approached the checkpoint at speed, hitting one of the barrels which formed part of the checkpoint. Shots were fired at the car by the Netherlands Lieutenant. It was not clear whether any of the ICDC had fired shots. ${ }^{19}$ The applicant's son, Azhar Sabah Jaloud, who was in the car at the time had died from the gunshots fired. ${ }^{20}$ The applicant brought a case to the ECtHR claiming that the Netherlands had breached the procedural duty under Article 2 right to life to carry out an effective and independent investigation into the death of his son. The ECtHR found that the Netherlands had jurisdiction under Article 1 and that, despite allowances made for the difficult circumstances under which they were undertaking their work, the Netherlands failed to provide an effective investigation under Article $2 .^{21}$

\footnotetext{
15 Gondek (2009), pp. 43-44.

16 Jaloud, supra n. 4, para. 10.

17 Ibid.

18 Ibid., para. 11.

19 Ibid., para. 12.

20 Ibid., para. 13.

21 Ibid., paras. 226-228.
} 
The Netherlands argued that the events complained of did not fall within the 'jurisdiction' of the Netherlands within the meaning of Article 1 of the ECHR as it was not an 'occupying power' under International Humanitarian Law and that only the US and UK were occupying powers by United Nations Security Council Resolution $1483 .{ }^{22}$ Furthermore, they had not assumed any public powers normally to be exercised by a sovereign government. ${ }^{23}$ Instead the Netherland's contingent was under the 'operational control of the commander of the Multinational Division, South East (MND (SE))', a UK officer. ${ }^{24}$ The Netherlands distinguished the present case from Al Skeini v. United Kingdom, ${ }^{25}$ wherein the UK had jurisdiction because the deaths had occurred as a result of actions of UK soldiers in the course of security operations whereas the death of Azhar Sabah Jaloud had occurred at a checkpoint manned by the ICDC. Although Netherlands personnel were present, there did not exist a 'hierarchical relationship' such that the Netherlands was responsible for what happened. ${ }^{26}$ Finally, the Netherlands argued that they should not be found to have exercised effective control over the checkpoint as this geographical area was so small that it would mean there would be no meaningful difference between the 'control over a territory' and 'control over an individual' tests of jurisdiction.

The applicant argued that the Netherlands had jurisdiction as, through their servicemen over which they officially exercised full command, ${ }^{27}$ it exercised public powers including enforcement of the Coalition Provisional Authority's authority and a security role. ${ }^{28}$ The Netherlands was exercising this public power when they were overseeing the ICDC at the checkpoint. ${ }^{29}$ The Netherlands also had jurisdiction by virtue of its effective military control over the area and additionally by virtue of the fact that it was an 'occupying power' within the meaning of Article 42 of the Hague Rules. ${ }^{30}$ Furthermore, the Netherlands had authority and control of the checkpoint including the Iraqi personnel manning it, and had carried out the investigation into Jaloud's death. ${ }^{31}$ Finally, the Netherlands Minister of Defence in his letter to Parliament of 18 June 2007 had endorsed the conclusion of the report of the Van den Berg Committee that the ECHR applied to Netherlands troops in Iraq. ${ }^{32}$

Under the question of 'jurisdiction' the ECtHR recited its own case law on Article 1 jurisdiction including Al Skeini ${ }^{33}$ which asserts the two main categories of Article 1 jurisdiction: effective control over a territory and state agent authority and

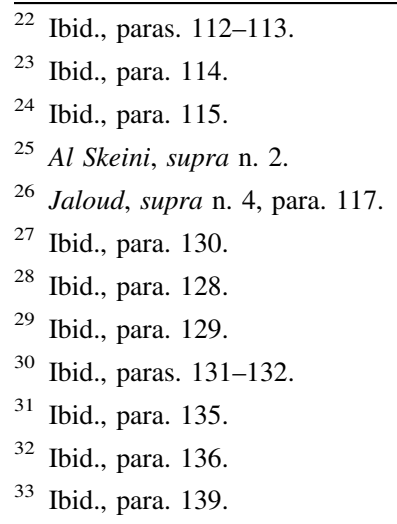


control. ${ }^{34}$ It found that whether a state was the 'occupying power' was not determinative of Article 1 jurisdiction. ${ }^{35}$ Under the same category of 'jurisdiction' the ECtHR then addressed to whom actions should be attributed. Agreeing with the applicants, the ECtHR stated that the respondent state was:

[...] not divested of its 'jurisdiction', within the meaning of Article 1 of the Convention, solely by dint of having accepted the operational control of the commander of the MND (SE), a United Kingdom officer. The Court notes that the Netherlands retained 'full command' over its military personnel, as the Ministers of Foreign Affairs and of Defence pointed out in their letter to Parliament (see paragraph 57 above). ${ }^{36}$

The ECtHR continued to answer to whom action should be attributed under the ‘jurisdiction' heading:

The practical elaboration of the multinational force was shaped by a network of Memoranda of Understanding defining the interrelations between the various armed contingents present in Iraq. The letter sent to the Lower House of Parliament on 6 June 2003 by the Ministers of Foreign Affairs and Defence (see paragraph 57 above) emphasises that the Netherlands Government retained full command over the Netherlands contingent in Iraq. ${ }^{37}$

It concluded that it appeared from the relevant sources that the drawing up of distinct rules on the use of force 'remained the reserved domain of individual sending states'. ${ }^{38}$ For this reason, the 'Netherlands assumed responsibility for providing security in that area, to the exclusion of other participating States, and retained full command over its contingents there'. ${ }^{39}$ It did not matter that the checkpoint was nominally manned by the ICDC because they were subordinate to the Coalition Forces. ${ }^{40}$ The Netherlands was not placed 'at the disposal' of, or 'under the exclusive direction or control' of any other state, referring to Article 6 of the ILC Draft Articles on State Responsibility and the Bosnian Genocide case. ${ }^{41}$

Under the separate heading of 'attribution', and following the above analysis, the ECtHR stated that " "jurisdiction" under Article 1 of the Convention has never been equated with the test for establishing a State's responsibility of an internationally wrongful act under general international law (see Catan, cited above, $\S 115$ )' ${ }^{42}$ It invoked Al Skeini to state that the Convention rights could be 'divided and tailored $^{43}$ and concluded its analysis of attribution by stating that:

\footnotetext{
34 Ibid. The ECtHR referred to Al Skeini, supra n. 2, paras. 130-139.

35 Ibid., para. 142.

36 Ibid., para. 143.

37 Ibid., para. 146.

38 Ibid., para. 147.

39 Ibid., para. 149.

40 Ibid., para. 150.

41 Ibid., para. 153.

42 Ibid., para. 154.

43 Ibid.
} 
The facts giving rise to the applicant's complaints derive from alleged acts and omissions of Netherlands military personnel and investigative and judicial authorities. As such they are capable of giving rise to the responsibility of the Netherlands under the Convention. ${ }^{44}$

The ECtHR proceeded to adjudicate upon whether there had been a breach of the investigative duty under Article 2. The ECtHR found that the Netherlands had carried out an independent investigation. ${ }^{45}$ However, the Netherlands had failed to carry out an effective investigation because important information had been withheld from judicial authorities and the applicant; no precautions had been taken to prevent the accused Lieutenant from 'colluding' with other witnesses before he was questioned; the autopsy was not carried out to the standard required; and important material evidence, including the bullet fragments taken from the victim's body, were mislaid. ${ }^{46}$

\subsection{A Conflation of Jurisdiction and Attribution}

Marko Milanovic argues that Jaloud confirms the already existing approach of the ECtHR entailing two different kinds of attribution tests related but separate from the concept of jurisdiction: one preceding the application of the jurisdiction test (attribution of jurisdiction-establishing conduct) and one following the application of the jurisdiction test (attribution of violation-establishing conduct). ${ }^{47}$ Jurisdictionestablishing conduct is the conduct (act or omission) which gives rise to the control over the territory or control over the individual, the two tests for establishing jurisdiction. Violation-establishing conduct is the act or omission which gives rise to the violation of the right. The preceding attribution test establishes who carried out the jurisdiction-establishing conduct and the succeeding attribution test establishes who carried out the violation.

Milanovic argues that the ECtHR resolved the attribution of jurisdiction question when it found that the Netherlands troops were not placed "at the disposal" of any foreign power ${ }^{48}$; the ECtHR addressed the separate 'jurisdiction' question when it stated that "the respondent Party exercised its "jurisdiction" within the limits of its SFIR [Stabilization Force in Iraq] mission and for the purpose of asserting authority and control over persons passing through the checkpoint ${ }^{\text {}}{ }^{49}$; attribution of the actual alleged violations was addressed under the separate heading of 'attribution' when the ECtHR stated that '[T]he facts giving rise to the applicant's complaints derive[d] from alleged acts and omissions of Netherlands military personnel and investigative and judicial authorities' and were therefore 'capable of giving rise to the responsibility of the Netherlands'. 50

\footnotetext{
44 Ibid., para. 155.

45 Ibid., para. 196.

46 Ibid., para. 227.

47 Milanovic (2014).

48 Ibid., citing para. 151.

49 Ibid., citing para. 152.

50 Ibid., citing para. 155.
} 
However, it is difficult to see how this reading can withstand scrutiny. The 'jurisdiction' section (from paras. 140-151 at the very least) is concerned with demonstrating that the Netherlands, rather than the occupying powers (the US and UK) or the ICDC manning the checkpoint, should be held responsible for the death of Azhar Sabah Jaloud. The ECtHR states that being an occupying power is not determinative of jurisdiction ${ }^{51}$; executing a decision or an order given by the authority of a foreign state is not determinative of jurisdiction ${ }^{52}$; and the fact that the checkpoint is nominally manned by the Iraqi ICDC is not determinative of jurisdiction. ${ }^{53}$ What was important for establishing jurisdiction was that the Netherlands had 'retained full command'. 54 'Full command' was the test that the ECtHR applied which attributed the actions to the Netherlands, and not to the ICDC or the UK and US.

In terms of paragraph 152, which Milanovic believes to be a paragraph separately resolving the question of Article 1 jurisdiction, the ECtHR states that Jaloud was killed while 'passing through a checkpoint manned by personnel under the command and direct supervision of a Netherlands Royal Army Officer'. This more closely resembles an attribution test rather than a control over the territory or authority and control over an individual test as the statement aims to establish which actor had the requisite control over the checkpoint rather than aiming to determine whether the type of control exercised over the individual was sufficient to establish jurisdiction over that individual. Furthermore, no Article 1 jurisdiction case law was cited in support of either test. The ECtHR further states that it 'exercised its "jurisdiction" within the limits of its SFIR mission' ${ }^{55}$ Again, this sentence appears to be corroborating earlier statements that it was within the Netherland's mandate to be in 'full command' of the events at the checkpoint. Although the ECtHR states that the Netherlands 'asserted authority and control' while 'exercising its "jurisdiction" within the limits of its SFIR mission" 56 this appears to be a rhetorical flourish rather than an assertion that it based its finding of jurisdiction on a 'state agent authority and control' test.

It does not appear that the section labelled 'attribution' establishes attribution of wrongful conduct, separate from the questions of both attributing jurisdiction and establishing jurisdiction, as is asserted by both Milanovic and Aurel Sari. ${ }^{57}$ There is no further analysis of whether any other actions should be attributed to the Netherlands, only the assertion that the ECtHR does not conflate jurisdiction with attribution. ${ }^{58}$ Aurel Sari, like Milanovic, maintains that this section indicates a separate test for attributing wrongful conduct. However, he argues that the 'full command' test-that was appropriately used to determine attribution of

\footnotetext{
51 Jaloud, supra n. 4, para. 142.

52 Ibid., paras. 143-149.

53 Ibid., para. 150.

54 Ibid., paras. 143, 147, 149.

55 Ibid., para. 152.

56 Ibid.

57 Sari (2014), pp. 292-293.

58 Jaloud, supra n. 4, para. 154.
} 
jurisdiction-was inappropriately applied in the 'attribution' section to determine attribution of wrongful conduct instead of the law of state responsibility. ${ }^{59} \mathrm{He}$ argues that the 'full command' test was applied by default in determining the attribution of wrongful conduct because of the lack of any further analysis under this section. ${ }^{60}$ This article argues that there was no further analysis because the ECtHR had already answered to whom the wrongful conduct should be attributed under the jurisdiction heading. Sari argues that the ECtHR determined Article 1 jurisdiction separately from determining attribution of jurisdiction and attribution of the wrongful conduct. He argues that the ECtHR established jurisdiction from three factors: assumption of authority by the Netherlands over the area, authority over the ICDC at the checkpoint, and the nature of the checkpoint as an instrument for asserting control over persons passing through it. ${ }^{61}$ However, the first two factors where arrived at through an attribution analysis. Furthermore, the checkpoint was not identified as a particular space which could constitute 'territory' for the purposes of the control over the territory test or as a method of control for exercising state agent authority and control over individuals. Rather, the point of emphasis was on which actor exercised control over the checkpoint where the shooting took place.

It appears that the ECtHR applied one test, one attribution test establishing to whom the rights-violating conduct should be attributed in the particular context, rather than three tests, before moving to the adjudication of the substantive right.

\section{Two Distinct Sub-tests of 'Effective Control'}

Does the conflation of attribution and Article 1 jurisdiction represent a new approach by the ECtHR? It will be argued here that this is not the first time that the ECtHR has conflated and denied conflating a test of attribution with Article 1 jurisdiction. It will be illustrated that the ECtHR has conflated attribution and Article 1 jurisdiction in the context of the 'effective control' test first articulated in Loizidou v. Turkey (preliminary objections). ${ }^{62}$ This case arose in the context of Turkish military operations in northern Cyprus in July and August 1974 which led to the subsequent division of Cyprus and to the establishment of a separatist regime, the Turkish Republic of Northern Cyprus (TRNC). In Loizidou, the applicant complained that the Turkish armed forces had prevented her from returning to northern Cyprus after the occupation and peacefully enjoying her property in the occupied area. In order to determine whether Turkey had obligations under the ECHR with respect to the applicant, the ECtHR found that:

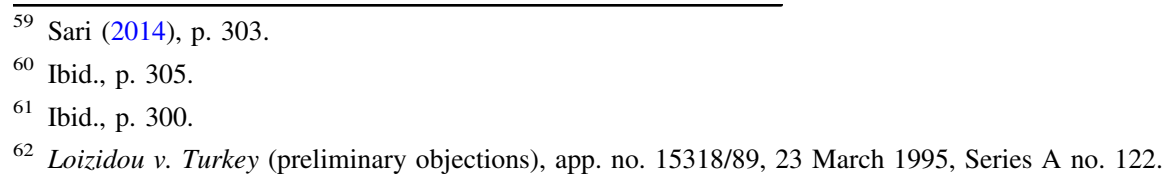


[...] the responsibility of a Contracting Party may also arise when as a consequence of military action-whether lawful or unlawful-it exercises effective control of an area outside its national territory. The obligation to secure in such an area, the rights and freedoms set out in the Convention derives from the fact of such control whether it be exercised directly, through its armed forces, or through a subordinate local administration. ${ }^{63}$

This test was interpreted in two ways both in the literature and in the case law that followed. One interpretation was that as a result of the control exercised by the respondent state over the territory, the respondent state had obligations under the ECHR towards everyone within that territory both to protect rights and to prevent rights violations by other individuals (the 'control over the territory' test). ${ }^{64}$ Another interpretation was that the rights violations carried out by the subordinate local administration could be attributed to the respondent state because of the control the respondent state exercised over the subordinate local administration (attribution test). ${ }^{65}$ Milanovic explains the 'control over the territory' test by reference to positive obligations. The positive obligations explanation provides that the respondent state, when it exercises control over the territory, must take positive actions to prevent others from committing rights violations within that territory. ${ }^{66}$ Milanovic posits that the ECtHR in Loizidou (preliminary objections) ${ }^{67}$ established that Turkey, by virtue of its effective overall control over northern Cyprus, had a positive obligation to prevent human rights violations, regardless of by whom they were committed. ${ }^{68}$

It is ambiguous as to which reading was applied by the ECtHR to the facts of Loizidou (preliminary objections) itself. After citing the effective control test above, the ECtHR stated that 'the applicant's loss of her property stemmed from the occupation of the northern part of Cyprus by Turkish troops and the establishment of the TRNC $[\ldots]^{69}$ This statement could be interpreted as suggesting that it was the Turkish occupation of the territory (control over the territory) or Turkey's establishment of the TRNC (attribution test) that was decisive for establishing jurisdiction. On an adjudication of the merits in Loizidou it was obvious from the 'large number of troops' in northern Cyprus that Turkey exercised 'effective overall control' thus entailing 'detailed control over the policies and actions of the authorities of the "TRNC". ${ }^{70}$ In the merits, therefore, it was still ambiguous as to whether the ECtHR applied a control over the territory or attribution test. Cyprus v.

\footnotetext{
63 Ibid., para. 62.

64 Milanovic (2011), p. 47. Miller (2009), p. 1223; Cassese (2007), p. 659, fn. 17; Wilde (2005), p. 115.

65 Gondek (2009), p. 164; Talmon (2009), p. 508; Ronen (2003), p. 535. Cyprus v. Turkey, app. no. 25781/94, ECHR 2001-IV, has been recognised as advocating an attribution test in order to establish Art. 1 jurisdiction: Orakhelashvili (2003), p. 545; Hakimi (2010), p. 377.

66 Milanovic (2011), p. 46.

67 Loizidou (preliminary objections), supra n. 62.

68 Milanovic (2011), p. 47.

69 Loizidou (preliminary objections), supra n. 62, para. 46.

70 Loizidou v. Turkey, app. no. 15318/89, ECHR 1996-VI, para. 56.
} 
Turkey $^{71}$ is also ambiguous. What was decisive in that case was whether 'Turkey actually exercised detailed control over the policies and actions of the authorities of the "TRNC", but the judges placed emphasis on the "effective overall control' of the territory as enabling Turkey to exercise control over that part of the territory. ${ }^{72}$ Turkey was responsible for 'the acts of the local administration which survive[d] by virtue of Turkish military and other support' ${ }^{73}$

In subsequent cases the Loizidou test is interpreted by the ECtHR as either a respondent's control over the territory test or as an attribution test. In Ilaşcu $v$. Moldova and Russia ${ }^{74}$ and Catan v. Moldova and Russia ${ }^{75}$ the ECtHR appears to have adopted an attribution test and in, for example, Banković v. Belgium ${ }^{76}$ and Saddam Hussein v. Albania ${ }^{77}$ the ECtHR applied the control over the territory test.

Both Ilasscu and Catan concerned rights violations carried out by the Moldovan Republic of Transdniestria (MRT). Following the declaration of the Republic of Moldova in June 1990, the 14th Army aided Transdniestrian separatists to set up the Moldovan Republic of Transdniestria in September 1990. ${ }^{78}$ In Ilaşcu, Russia was found to have violated Article 3 (right against torture and inhumane and degrading treatment and punishment) and Article 5 (right to liberty and security) with regards to all of the applicants concerned from the date of its ratification of the Convention. ${ }^{79}$ The judgment was focused predominantly upon establishing links between Russia and the MRT itself which included its historical links: during the Moldovan conflict in 1991-1992, forces of the 14th Army stationed in Transdniestria fought with and on behalf of the Transdniestrian separatist forces ${ }^{80}$; throughout 'clashes between the Moldovan authorities and the Transdniestrian separatists, the leaders of the Russian Federation supported the separatist authorities by their political declarations ${ }^{81}$; Russia had provided the separatists with large quantities of weapons ${ }^{82}$; separatists had seized possession of other weapons unopposed by Russian soldiers. ${ }^{83}$ In terms of the present day connections between Russia and the MRT, the Court attached particular importance to the fact that the MRT enjoyed financial support from the Russian Federation. ${ }^{84}$ The Russian Federation cleared the MRT's debt to it, supplied gas to Transdniestria on better financial terms than to Moldova, and state-controlled companies of the Russian Federation entered into

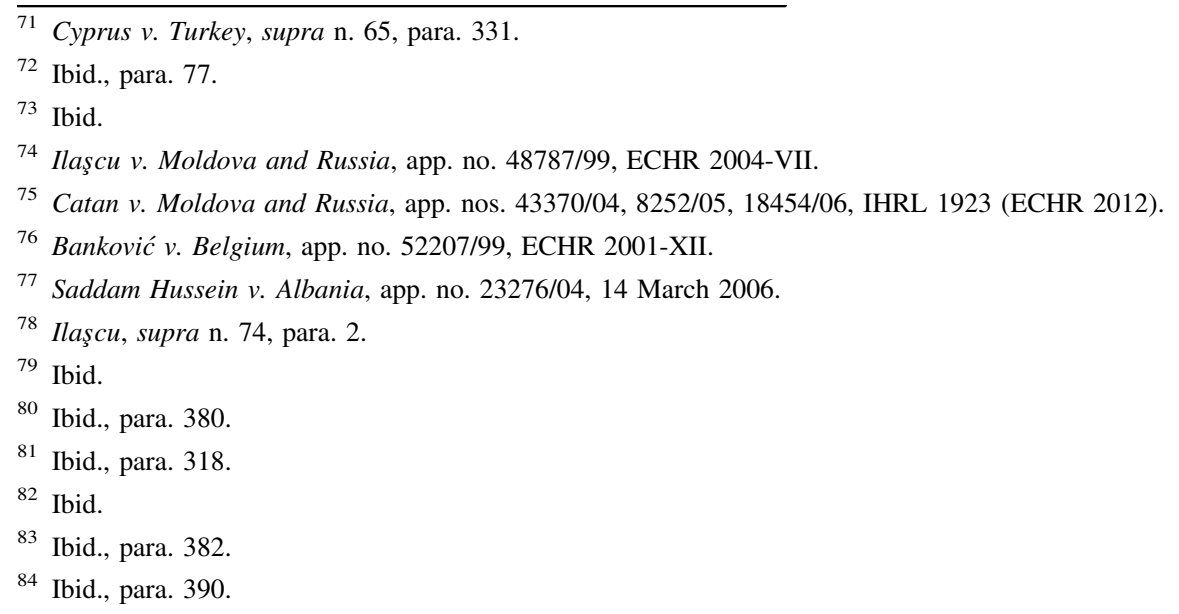


commercial relations with companies in the MRT. ${ }^{85}$ The fact that Russia helped to install the MRT with military aid, and enabled its survival with financial aid, were crucial to holding Russia responsible for the acts of the MRT. The point of emphasis was whether there was sufficient control or influence exercised by Russia over the MRT rather than sufficient control over the territory. The Court noted that after the ceasefire the 'Russian Federation continued to provide military, political and economic support to the separatist regime (see paragraphs $111-61$ above), thus enabling it to survive by strengthening itself and by acquiring a certain amount of autonomy vis-à-vis Moldova'. ${ }^{86}$ The ECtHR did not use a positive obligations explanation to explain Russia's extraterritorial obligations under the ECHR despite the fact that it used positive obligations to explain the obligations of Moldova- the territorial state on which the separatist regime was situated. ${ }^{87}$ If the ECtHR had intended to use a positive obligations explanation in relation to Russia's extraterritorial obligations, it had created an opening for doing so. The fact that it did not is further evidence for suggesting that an attribution test was applied in this case.

In Catan the ECtHR went into much greater detail concerning both the historical and contemporary links between Russia and the MRT ${ }^{88}$ It repeated the factors that it had considered crucial in Ilaş $\mathrm{Cu}^{89}$ and also added more specific considerations. For example, it noted that in April 1992, the Russian Army stationed in Transdniestria intervened in the conflict allowing the separatists to gain possession of Tighnia. ${ }^{90}$ The Russian public corporation Gazprom supplied gas to the region and the MRT paid for only a tiny fraction of the gas consumed. ${ }^{91}$ Furthermore, the Russian Government had spent millions of US dollars every year in the form of humanitarian aid to the population of Transdniestria, including the payment of old age pensions, financial assistance to schools, hospitals and prisons. ${ }^{92}$ This was even more significant considering the fact that only $20 \%$ of the MRT population was economically active. ${ }^{93}$ It appears the ECtHR attempted to demonstrate the control and influence that Russia had on the MRT in order to attribute the actions of the MRT to Russia.

In contrast to Ilaşcu and Catan which appeared to apply an attribution test, the cases of Banković v. Belgium ${ }^{94}$ and Saddam Hussein v. Albania ${ }^{95}$ applied a control over the territory test. Banković concerned airstrikes carried out by the North Atlantic Treaty Organisation (NATO) on the territory of the Federal Republic of

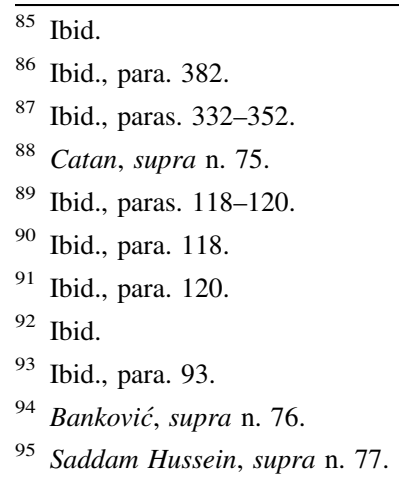


Yugoslavia (FRY) during the conflict in Kosovo between Serbian and Kosovar Albanian forces during 1998 and 1999. A Radio Televizije Srbije (RTS) building was hit by a missile launched from a NATO forces' aircraft. The ECtHR invoked the public international law definition of jurisdiction in order to determine the 'ordinary meaning' of jurisdiction within Article 1 as was required by the customary rules of treaty interpretation reflected in Article 31(1) of the Vienna Convention on the Law of Treaties 1969. Aside from specific factual incidences in which the ECHR could be applied abroad, ${ }^{96}$ the ECtHR provided that the ECHR would apply extraterritorially only in 'exceptional' circumstances, when 'through the effective control of the relevant territory and its inhabitants abroad as a consequence of military occupation or through the consent, invitation or acquiescence of the Government of that territory' the respondent state 'exercises all or some of the public powers normally to be exercised by that Government'. 97

In applying this test, the ECtHR expressly asserted that 'the scope of Article 1 [...] is determinative of the very scope of the Contracting Parties' positive obligations and, as such, of the scope and reach of the entire Convention system' ${ }^{98}$ It rejected a 'cause-and-effect' notion of jurisdiction meaning that it rejected the idea that a state could be held responsible for a specific, singular incident of rightsviolation abroad, but would rather be held responsible under the entire breadth of the ECHR towards everyone within that territory. ${ }^{99}$ In this way rights under the ECHR could not be 'divided and tailored'. ${ }^{100}$ The ECtHR found in that case that the NATO states carrying out the bombing did not exercise sufficient "control over the territory' to establish Article 1 jurisdiction because there had been no military occupation and no exercise of public powers.

Saddam Hussein v. Albania also adopted the 'control of the territory' test. ${ }^{101}$ The Hussein case arose as a result of the invasion by the US and UK in Iraq. The former President of Iraq, Saddam Hussein complained that as a result of his 'arrest, detention, handover and ongoing trial' the states involved were in violation of Article 2 (right to life), Article 3 (right against torture and inhumane and degrading treatment), Article 5 (right to liberty and security) and Article 6 right to a fair trial, as well as Article 1 of the 6th and 13th Protocols. Without any thorough analysis of the nature of the control exercised by any of the states over the territory of Iraq, the ECtHR concluded that Hussein had not demonstrated that any of the states had 'control of the territory where the alleged violations took place' citing Loizidou $v$. Turkey and Cyprus v. Turkey. ${ }^{102}$

It appears that the test in Loizidou (preliminary objections) is ambiguous and can be interpreted to mean an attribution or control over the territory test: perhaps Turkey had responsibility under the ECHR because of its control over the TRNC or

\footnotetext{
96 Banković, supra n. 76, paras. 67-79, 73.

97 Ibid., para. 74.

98 Ibid., para. 65 .

99 Ibid., para. 75.

100 Ibid.

101 Saddam Hussein, supra n. 77.

102 Ibid.
} 
because of its control over the territory in northern Cyprus. However, it is clear in Ilaşcu and Catan that the ECtHR focused on establishing a control link between the respondent state and the separatist regime, the MRT, rather than control over the territory; and Bankovic and Hussein both explicitly applied the control over the territory approach.

\section{Unsound Methodology and Conflicts with International Law}

\subsection{Unsound Methodology}

It has been argued that attribution should not be conflated with Article 1 jurisdiction because the law of state responsibility is a separate issue from jurisdiction under international human rights treaties. ${ }^{103}$ Gondek states that it is not methodologically correct to conflate attribution and jurisdiction under human rights treaties. ${ }^{104} \mathrm{He}$ finds that the rules of state responsibility deal only with determining whether an 'obligation has been violated and what should be the consequences of the violation', rather than with 'defining the rule and the content of the obligation it imposes', citing the ILC Rapporteur Roberto Ago. ${ }^{105}$ Rules of state responsibility are 'secondary' providing 'the general conditions under international law for the state to be considered responsible for wrongful actions or omissions, and the legal consequences flowing therefrom'. ${ }^{106}$ Primary rules define the content of the international legal obligation breached. ${ }^{107}$ Gondek distinguishes state responsibility from jurisdiction: "[t]he issue whether a person is within the jurisdiction of a state within the meaning of human rights treaties is not a question of attributability of an act to a state, which belongs to secondary rules of state responsibility'. ${ }^{108}$

Article 2 states that there is an internationally wrongful act of a state when conduct consisting of an action or omission is attributable to the state under international law (Article 2(a)) and constitutes a breach of an international obligation of the state (Article 2(b)). ${ }^{109}$ Both Gondek $^{110}$ and Milanovic ${ }^{111}$ provide that jurisdiction under Article 1 of the ECHR establishes whether there has been a breach of obligations as they determine to whom substantive obligations are owed, therefore falling under Article 2(b) of ASR. Sarah H. Cleveland, however, argues

\footnotetext{
103 Gondek (2009), pp. 165-168; Milanovic (2011), pp. 51-52.

104 Gondek (2009), p. 164.

105 Ibid., p. 163, citing ILC, Yearbook of the International Law Commission 1970, Vol. II, p. 306, para. 66(c).

106 Ibid., p. 164, citing Crawford (2002), p. 74.

107 Ibid.

108 Ibid.

109 Art. 2 states: 'There is an internationally wrongful act of a State when conduct consisting of an action or omission: (a) is attributable to the State under international law; and (b) constitutes a breach of an international obligation of the State.'

110 Gondek (2009), p. 168.

111 Milanovic (2011), p. 273.
} 
that jurisdiction in international human rights treaties is closely linked to the international law concept of state responsibility: 'it is the exercise of jurisdiction that gives rise to legal obligations under the treaty'. ${ }^{112}$ She cites tests of state responsibility and attribution applied in ICJ case law which determine whether treaty obligations arise to elucidate the concept of jurisdiction in international human rights treaties. ${ }^{113}$ Olivier De Schutter argues that the question of jurisdiction under international human rights treaties 'precedes' the two questions in Article 2. ${ }^{114}$ It is the preliminary threshold question before any questions of state responsibility. ${ }^{115}$

Contrary to Gondek and Milanovic, jurisdiction does not appear to be determinative of whether an action or omission 'constitutes a breach of an international obligation of the state' and is not determinative of the definition or the 'content' of an ECHR obligation. ${ }^{116}$ It establishes whether the ECHR is in operation at all when the state is acting abroad. The content of an ECHR obligation and whether there has been a breach of a right under the ECHR is determined by an adjudication upon the merits. Cleveland acknowledges that jurisdiction is a separate question from establishing whether there has been a breach of an international obligation. The function of jurisdiction-establishing whether a treaty obligation is in operation at all-is much more closely aligned to state responsibility. What is important to acknowledge is that there is no consensus on what Article 2 of the ASR has to say about the relationship between jurisdiction and state responsibility. The lack of consensus on the interpretation of Article 2 may be evidence of the fact that Article 2 does not have anything to say about that relationship. ${ }^{117}$ In any case, it cannot be conclusively said that Article 2 precludes a conflation of attribution and jurisdiction under international human rights treaties. Therefore, it is not necessarily an unsound methodology to conflate attribution and jurisdiction under international law. There is even support for the proposition that jurisdiction and state responsibility carry out the same function of determining whether legal obligations under a treaty arise in the first place. ${ }^{118}$

\footnotetext{
112 Cleveland (2010), p. 233.

113 Ibid., pp. 233-234 citing Case Concerning Military and Paramilitary Activities in and Against Nicaragua (Merits), Judgment of 27 June 1986, ICJ Reports 1986, p. 14, paras. 105-115. Application of the Convention on the Prevention and Punishment of the Crime of Genocide (Bosnia and Herzegovina $v$. Serbia and Montenegro), Judgment of 26 February 2007, ICJ Reports 2007, p. 43 paras. 391-406; Legal Consequences for States of the Continued Presence of South Africa in Namibia (South West Africa) Notwithstanding Security Council Resolution 276 (1970), Advisory Opinion of 21 June 1971, ICJ Reports 1971, p. 16.

114 De Schutter (2006), p. 189.

115 Ibid., p. 190.

116 ILC, Yearbook of the International Law Commission 1970, Vol. II, p. 306, para. 66(c).

117 See ILC, Articles on State Responsibility, supra n. 13, pp. 34-36; Crawford (2013); Crawford et al. (2010).

118 Cleveland (2010), p. 233.
} 


\subsection{Conflicts with International Law}

In addition to the conceptual debate on the relationship between jurisdiction and state responsibility, there is concern that a conflation of attribution and Article 1 jurisdiction would unavoidably conflict with standards of attribution under the law of state responsibility prescribed by the ICJ and in the ASR. ${ }^{119}$ This has been put forward as a reason for denying conflation of attribution and Article 1 jurisdiction. This concern has arisen specifically in the context of states' relationships with separatist groups in other countries, such as in relation to the TRNC and MRT decisions. The same concern has not arisen in the context of multinational military operations. The ECtHR has adopted attribution tests that are contrary to those prescribed under the ASR and 'Draft articles on the Responsibility of International Organisations' in the context of multi-national military operations. ${ }^{120}$ However, these concerns have never been put forward as a reason for denying the conflation of attribution with Article 1 jurisdiction. This section addresses a very particular debate that arose in relation to two ICJ decisions, Nicaragua and the Bosnian Genocide case ${ }^{121}$; one International Criminal Tribunal of the Former Yugoslavia (ICTY) decision, Tadic ${ }^{122}$; and Loizidou v. Turkey. ${ }^{123}$ It challenges the argument that these cases and relevant articles of the ASR demonstrate that attribution cannot be conflated with Article 1 jurisdiction in ECtHR jurisprudence.

The ASR provides the starting point for understanding attribution in international law. Article 4(1) ASR provides that conduct of a state's own organs is always attributable to states. ${ }^{124}$ Furthermore, acts by a non-state actor performed under the 'direction, instigation or control of state organs' can also be attributed to the state. ${ }^{125}$ Attributing the actions of a non-state entity to a state does not merely arise from a factual causal link between those actions and the state, ${ }^{126}$ but rather is determined by further provisions in the ASR and also in the adjudication of cases brought before relevant international courts. Nicaragua, the Bosnian Genocide case and Tadić all provide guidance on how attribution should be understood under international law.

In Nicaragua the ICJ set out two tests for attributing the actions of a non-state entity - which was not a de jure organ of the state - to a state: a test requiring the establishment of control over the particular conduct in question (complete dependence) and a test requiring the establishment of control over the entity

\footnotetext{
119 Milanovic (2011), pp. 43-44.

120 ILC, 'Report of the International Law Commission on the Work of its $63^{\text {rd }}$ Session' (2011), UN Doc. A/66/10; ILC, Yearbook of the International Law Commission 2011, Vol. II, Part Two. See further: Larsen (2008), p. 509; Sari (2008), p. 151; Krieger (2009), p. 159; (Bell 2009-2010), p. 501.

121 Nicaragua, supra n. 113; Bosnian Genocide case, supra n. 113.

122 Prosecutor v. Tadić, IT-94-1, Trial Chamber, Judgment, 7 May 1997; Prosecutor v. Tadić, IT-94-1, Appeals Chamber, Judgment, 15 July 1999.

123 Loizidou (preliminary objections), supra n. 62; Loizidou (merits), supra n. 70.

124 ILC, Articles on State Responsibility, supra n. 13, p. 40.

125 Crawford (2002), p. 91.

126 Ibid.
} 
(effective control). ${ }^{127}$ The ICJ aimed to ascertain whether the US could be held responsible for violations of International Humanitarian Law (IHL) carried out by contras in Nicaragua. The test applied was whether the relationship between the contras and the US Government was 'so much one of dependence on the one side and control on the other' that the contras should be equated with an organ of the state for legal purposes. ${ }^{128}$ The ICJ found that apart from the aid that was provided to the contras they were otherwise an 'independent force'. ${ }^{129}$ The ICJ asked itself whether the provision of aid by the US to the contras was sufficient for declaring the contras to be acting on behalf of the US. ${ }^{130}$ It noted that when military aid was ceased contra activity continued. ${ }^{131}$ Therefore, although US support was 'crucial' to the contra's conduct, their 'complete dependence' on US aid was not demonstrated. ${ }^{132}$ Although there was one stage where US support was crucial this was not demonstrated in relation to the majority of acts that were carried out. ${ }^{133}$ Sufficient control was not found despite the fact that 'political leaders of the contra force had been selected, installed and paid by the United States' and despite their participation in the 'organization, training and equipping of the force, the planning of operations, choosing of targets and the operational support provided' ${ }^{134}$ The ICJ concluded that it did not have sufficient evidence to determine the US's involvement, and did not think that it had been clearly demonstrated that the contras had 'no real autonomy'. 135

The ICJ then applied another test with a lower threshold of control: "effective control of the military or paramilitary operations in the course of which the alleged violations were committed'. ${ }^{136}$ Sufficient control could be established if the US could be found to have exercised general 'effective control' of the military and paramilitary operations. Nicaragua indicates that the ICJ will apply a test of 'complete dependence' when establishing whether a particular activity can be attributed to the respondent state, and a test of 'effective control' when establishing whether, more generally, the actions of a non-state entity can be attributed to the respondent state. Therefore, the standard of control required for attribution in Nicaragua was much higher than in the ECtHR decisions in Ilaşcu or Catan. ${ }^{137}$

At the ICTY, the Trial Chamber in Tadic chose to determine whether there existed a state of international armed conflict by asking whether forces of Bosnian

\footnotetext{
127 Nicaragua, supra n. 113, paras. 105-115; Bosnian Genocide case, supra n. 113, paras. 391-406; Milanovic (2006), p. 576. For those that interpret the Nicaragua test as one test see: Cassese (2007), p. 652; Meron (1998), p. 236; Chase (2004), p. 41.

128 Nicaragua, supra n. 113, para. 109.

129 Ibid.

130 Ibid.

131 Ibid., para. 110.

132 Ibid.

133 Ibid., para. 111.

134 Ibid., para. 112.

135 Ibid., paras. 114-115.

136 Ibid., para. 115.

137 Ilaşcu, supra n. 74; Catan, supra n. 75.
} 
Serbs had remained agents of FRY after the withdrawal of Yugoslav troops from Bosnia in May 1992. ${ }^{138}$ It used the law of state responsibility and the tests of control laid down in Nicaragua in order to determine whether there was an international armed conflict. The Appeal Chamber of the ICTY disagreed with the test of control adopted in Nicaragua. It found that in order for the actions of an individual to be attributed to the state, the state had to exercise 'effective control' over that individual, but it asserted that the degree of control could vary according to the factual circumstances of each case. ${ }^{139}$ A single, private individual would need specific instructions from the state for their actions to be attributable to the state but a group would require a different standard of control for their actions to be attributed to the state. ${ }^{140}$ It was sufficient for the group to be under the overall control of the state for attribution to occur. The Appeals Chamber found in Tadic that the state coordinating or helping in the general planning of the non-state actor's military activity was sufficient control for attribution of conduct to the respondent state. ${ }^{141}$ The Appeal Chamber relied on Loizidou to justify a much lower threshold of control required for the attribution test, stating that in that case the 'Court did not find it necessary to ascertain whether the Turkish authorities had exercised "detailed" control over the specific "policies and actions" of the authorities of the "TRNC", 142

Article 8 ASR adopted the Nicaragua test as the test of attribution of conduct of non-state entities to a state. It attributed to a state conduct by persons or groups of persons acting 'on the instructions', or 'under the direction' or 'under the control' of the state. The Commentary to Article 8 distinguished Tadic from Nicaragua by stating that the question in Tadic was concerned with applicable rules of international law rather than state responsibility. ${ }^{143}$ In the Bosnian Genocide case, the ICJ rejected the test in Tadic. ${ }^{144}$ In that case the ICJ had to determine whether acts of genocide carried out at Srebrenica in the former Yugoslavia (FRY) by Bosnian Serb armed forces (VRS) were attributable to FRY. Having established that members of VRS were not de jure organs of FRY and could not be likened to organs of the FRY because they did not have 'complete dependence' on it, ${ }^{145}$ it then considered whether the VRS could be considered as a de facto organ of FRY. The ICJ applied the 'effective control' test from Nicaragua. ${ }^{146}$ It did so because the Nicaragua test coincided with the standards required by the ILC in Article 8 ASR. ${ }^{147}$ Similar to the Commentary for Article 8, the ICJ rejected Tadic firstly because it did not apply the test to a situation which concerned state responsibility

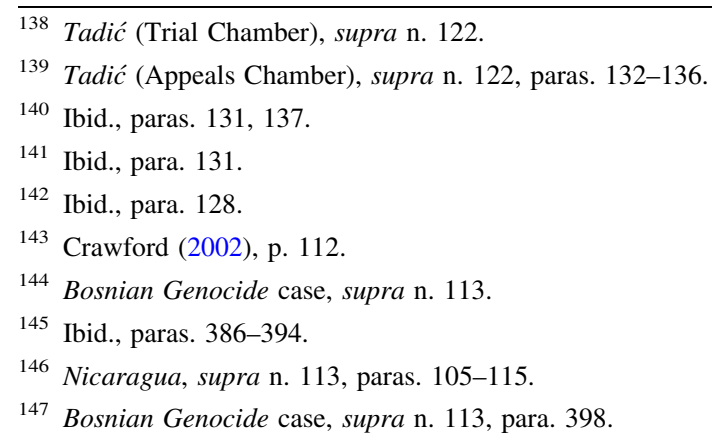


but rather in order to determine whether the conflict was international or not ${ }^{148}$; and secondly, it broadened the scope of state responsibility because it went beyond the standards set out by the ILC in Article 8 of the ARS. ${ }^{149}$

The ICJ and ILC's explicit rejection of Tadićs adoption of an attribution test based on Loizidou has been stated as evidence of the fact that the ECtHR's Article 1 jurisprudence cannot be interpreted as employing an attribution test because it would not be in conformity with international law. ${ }^{150}$ International law on state responsibility does not admit of a lower standard of control for attributing the actions of a non-state actor to a state. But does the ICJ and ILC's rejection of Tadić necessarily entail a rejection of a lower standard of control for attribution in all other circumstances? Cassese has argued that if the ICTY had stated that it was applying a test in order to establish whether the armed conflict was an international one-and not necessarily dictating general rules on state responsibility-then that would be permissible. ${ }^{151}$ Would a lower standard of control for attribution in the human rights context ever be permissible under international law?

The ILC prepared a report on the fragmentation of international law entitled 'Fragmentation of International Law: Difficulties Arising from the Diversification and Expansion of International Law' (the 'Fragmentation Report') with Martti Koskenniemi as Chairman. ${ }^{152}$ The Fragmentation Report sought to determine whether the emergence of new 'self-contained regimes' such as human rights regimes, trade regimes, environmental regimes as well as other geographically or functionally limited treaty regimes 'created problems of coherence in international law'. ${ }^{153}$ It acknowledged that in conditions of 'social complexity' it was 'pointless to insist on formal unity' of international law. ${ }^{154}$ However, it also recognised the tension that existed between different rules and standards in international law and attempted to suggest means of resolving those tensions by using techniques of judicial interpretation. ${ }^{155}$

The Fragmentation Report considered the different tests of attribution prescribed in Nicaragua and Tadic. ${ }^{156}$ It found that two types of problems arose from this kind of norm conflict: legal subjects would no longer be able to predict the standard which would be applied to them and to plan around those standards; and it would put legal subjects in an unequal position in relation to each other because their

\footnotetext{
148 Nicaragua, supra n. 113, paras. 103-105.

149 Bosnian Genocide case, supra n. 113, para. 406.

150 Milanovic (2011), pp. 43-51.

151 Cassese (2007), p. 651.

152 ILC, 'Report of the International Law Commission on the Work of its $58^{\text {th }}$ Session' (1 May-9 June and 3 July-11 August 2006), UN Doc. A/CN.4/L.682, http://legal.un.org/ilc/documentation/english/a_ cn4_1682.pdf.

153 Ibid., p. 14, para. 15.

154 Ibid., p. 15, para. 16.

155 Ibid., p. 15, para. 18.

156 Ibid., p. 32, para. 50. The Fragmentation Report did concede in fn. 52 that " $\mathrm{t}$ ]his need not be the only-nor indeed the correct-interpretation of the contrast between the two cases. As some commentators have suggested, the cases can also be distinguished from each other on the basis of their facts. In this case, there would be no normative conflict.'
} 
rights, rather than depending on a coherent legal framework, would depend upon which court had jurisdiction to hear the case or which forum was chosen by those party to the case. ${ }^{157}$ The two possible solutions it posited for solving this kind of conflict was firstly, by states adopting a new law that settled the conflict, or secondly, by institutions coordinating the conflict in the future. ${ }^{158}$

The Fragmentation Report provides a number of methods for coordinating conflicting norms. Two methods may be of significance for the ECtHR's adoption of a different attribution test to that prescribed by general international law. The ECtHR could distinguish its approach from that prescribed by general international law under lex specialis and by virtue of its 'regionalist' character. The principle of lex specialis derogat legi generali provides special law derogates from general law and is one of the interpretation techniques recommended by the Fragmentation Report for justifying diverging standards from general international law. ${ }^{159}$ Lex specialis can provide an 'elaboration, updating or technical specification' of the general standard of a particular rule. ${ }^{160}$ Lex specialis operates upon the principle that 'special rules are better able to take account of particular circumstances'. ${ }^{161}$ The ILC Commentary to Article 55 of the ASR states that '[ $t$ ]hese articles do not apply where and to the extent that the conditions for the existence of an internationally wrongful act or the content or implementation of the international responsibility of a state are governed by special rules of international law'. ${ }^{162}$ The articles have a 'residual character' in relation to the special rules. ${ }^{163}$ The ECtHR could therefore argue that it is operating with a lower standard of control for attributing action of a non-state entity to a state in order to improve human rights protection.

The Fragmentation Report recognises 'regionalism' as the 'pursuit of geographical exceptions to universal international rules' ${ }^{164}$ Certain rules are only binding on states that are members of a particular region. ${ }^{165}$ It could be argued that the ECHR was an instrument of 'European public order' in which a unique set of standards applied because of the regional character of the ECHR, thus justifying a lower standard of control for establishing attribution than that required under general international law. ${ }^{166}$ It follows that the ECtHR is not necessarily prohibited under international law from taking a different approach to the ICJ in the Bosnian Genocide case and to Article 8 ASR, so long as the ECtHR explicitly distinguishes and justifies its own approach using established techniques of interpretation.

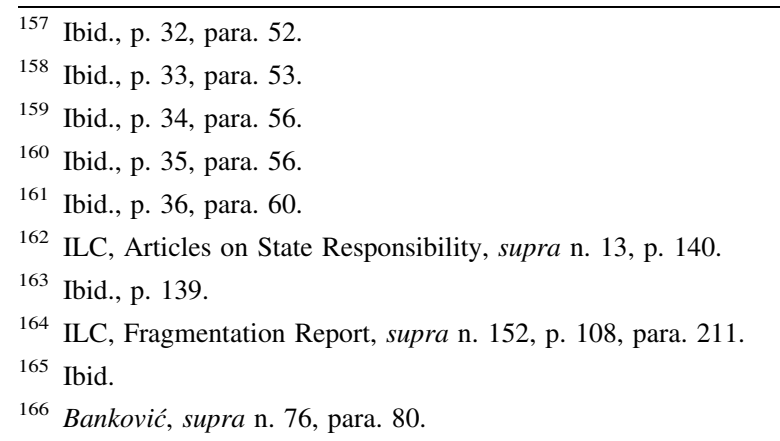




\section{Conclusion}

The ECtHR explicitly accepts two tests for the extraterritorial application of the ECHR under Article 1 of the ECHR: the control over an individual test and the control over a territory test. The ECtHR in Jaloud $v$. Netherlands could be interpreted as adopting a different test of jurisdiction under Article 1: an attribution test. It has been argued here that this would not be the first time that the ECtHR has adopted an attribution test in order to establish Article 1 jurisdiction. In Ilaşcu and Catan the ECtHR relied on attributing the actions of the MRT to Russia in order to hold Russia responsible for the rights violations committed by the MRT. Furthermore, this approach does not give rise to an insurmountable conflict with international law. Article 2 of the ASR does not necessarily preclude the conflation of attribution and Article 1 jurisdiction. Whether it provides any guidance on the relationship between jurisdiction and attribution in international human rights treaties is inconclusive. Furthermore, the fact that the standard of control required under international law for attributing the actions of non-state entities to states is higher than in the ECtHR's jurisprudence is not, in and of itself, a reason for denying conflation of attribution with jurisdiction. One way in which the ECtHR can justify its distinct practice is by reference to its character as a regional international human rights treaty. If Article 1 jurisdiction is conflated with attribution, then it signals a move towards the diminishing significance of territory as a barrier to accountability under the ECHR. The arbitrary tests for determining when the ECHR is applicable abroad - the control over an individual or control over a territory tests-are overlooked, and the question becomes: who should be held responsible?

Acknowledgments I would like to thank Professor Fiona de Londras and Dr Henry Jones for their suggestions on this article. I would also like to thank the anonymous reviewers for their invaluable comments. All errors are my own.

Open Access This article is distributed under the terms of the Creative Commons Attribution 4.0 International License (http://creativecommons.org/licenses/by/4.0/), which permits unrestricted use, distribution, and reproduction in any medium, provided you give appropriate credit to the original author(s) and the source, provide a link to the Creative Commons license, and indicate if changes were made.

\section{References}

Bell CA (2009-2010) Reassessing multiple attribution: the International Law Commission and the Behrami and Saramati Decision. N Y Univ J Int Law and Politics 42:501-548

Cassese A (2007) The Nicaragua and Tadic tests revisited in light of the ICJ Judgment on Genocide in Bosnia. EJIL 18:649-668

Chase AE (2004) Legal mechanisms of the international community and the United States concerning state sponsorship of terrorism. Va J Int Law 45:41-137

Cleveland SH (2010) Embedded international law and the constitution abroad. Columbia Law Rev 110:225-288 
Crawford J (2002) The International Law Commission's Articles on State Responsibility: introduction, text and commentaries. Cambridge University Press, Cambridge

Crawford J (2013) State responsibility: the general part. Cambridge University Press, Cambridge

Crawford J et al (eds) (2010) The law of international responsibility. Oxford University Press, Oxford

De Schutter O (2006) Globalisation and jurisdiction: lessons from the European Convention on Human Rights. Balt Yearb Int Law 6:185-247

Gondek M (2009) The reach of human rights in a globalising world: extraterritorial application of human rights treaties. Intersentia, Antwerp

Hakimi M (2010) State bystander responsibility. EJIL 21:341-385

Krieger H (2009) A credibility gap: the Behrami and Saramati decision of the European Court of Human Rights. J Int Peacekeeping 13:159-180

Larsen KM (2008) Attribution of conduct in peace operations: the 'ultimate authority and control' test. EJIL 19:509-531

Lawson R (2004) Life after Bankovic: on the extraterritorial application of the European Convention on Human Rights. In: Coomans F, Kamminga MT (eds) Extraterritorial application of human rights treaties. Intersentia, Antwerp, pp 83-123

Meron T (1998) Classification of armed conflict in the Former Yugoslavia: Nicaragua's fallout. AJIL 92:236-241

Milanovic M (2006) State responsibility for genocide. EJIL 17:553-604

Milanovic M (2011) Extraterritorial application of human rights treaties: law, principles and policy. Oxford University Press, Oxford

Milanovic M (2014) Jurisdiction, attribution and responsibility in Jaloud. EJIL: Talk! 11 December 2014. http://www.ejiltalk.org/jurisdiction-attribution-and-responsibility-in-jaloud/. Accessed 12 Oct 2015

Miller S (2009) Revisiting extraterritorial jurisdiction: a territorial justification for extraterritorial jurisdiction under the European Convention. EJIL 20:1223-1246

Orakhelashvili A (2003) Restrictive interpretation of human rights treaties in the recent jurisprudence of the European Court of Human Rights. EJIL 14:529-568

Ronen Y (2003) Non-recognition, jurisdiction and the TRNC before the European Court of Human Rights. Camb Law J 62:534-537

Sari A (2008) Jurisdiction and international responsibility in peace support operations: the Behrami and Saramati cases. Hum Rights Law Rev 8:151-170

Sari A (2014) Untangling extra-territorial jurisdiction from international responsibility in Jaloud v. Netherlands: old problem, new solutions? Mil Law Law War Rev 53:287-318

Talmon S (2009) The responsibility of outside powers for acts of secessionist entities. ICLQ 58:493-518

Wilde R (2005) The 'legal space' or 'espace juridique' of the European Convention on Human Rights: is it relevant to extraterritorial state action? Eur Hum Rights Law Rev 10:115-124 